\title{
The Relationship between Spiritual Well-Being and Happiness: An Investigation on Teachers
}

\author{
Mustafa Özgenel $^{1}$ \\ İstanbul Sabahattin Zaim University
}

\author{
Özden Yılmaz $^{2}$ \\ Bilim Koleji/Science College
}

"This article was produced from Özden Yllmaz's master thesis which was conducted under the supervision of Dr. Mustafa Özgenel.

${ }^{1}$ Assoc. Prof., Faculty of Education, Istanbul Sabahattin Zaim University, Istanbul, Turkey. E-mail: mustafa.ozgenel@izu.edu.tr

${ }^{2}$ School Principal, Bilim Koleji/Science College, Istanbul, Turkey. E-mail: ozdenyilmaz1@hotmail.com

\begin{abstract}
This study aims to examine the relationship between teachers' spiritual well-being and happiness levels. Being quantitative in nature, this study employs a relationship survey model. A total of 390 teachers employed in various grades of different types of schools (i.e., primary schools, middle schools, Imam-Khatib middle schools, Anatolian-science high schools, Imam-Khatib high schools, and vocational high schools) in Istanbul's Küiçïkçekmece district volunteered to participate in this study. The Personal Information Form, the Spiritual Well-Being Scale, and the Oxford Happiness Questionnaire were employed to collect data, which were then analyzed using Pearson's correlation coefficient and a regression analysis. The results of these analyses reveal that happiness is significantly and positively correlated with transcendence and harmony with nature whereas happiness is significantly and negatively correlated with anomie. While transcendence positively affects teachers' happiness, anomie negatively affects them. It has been found that this effect size is medium. Another important finding obtained in the study is that harmony with nature, one of the sub-dimensions of spiritual well-being, does not affect teachers' happiness.

Keywords:

Well-being • Spiritual well-being $\bullet$ Happiness
\end{abstract}

\section{Spiritüel İyi Oluş ile Mutluluk Arasındaki İlişki: Öğretmenler Üzerine Bir İnceleme}

Öz

Corresponding author:

Mustafa Özgenel

E-mail:

mustafa.ozgenel@izu.edu.tr

eISSN: 2458-9675

Received: 11.05 .2020

Revision: 19.06.2020

Accepted: 03.09.2020

(C)Copyright 2020

by Author(s)
Araştırmanın amacı, öğretmenlerin spirituiel iyi oluşları ile mutluluk düzeyleri arasındaki ilişkiyi incelemektir. Çalışmada nicel araştırma yöntemlerinden ilişkisel tarama modeli kullanılmıştır. Araştırmaya İstanbul ili Küçüikçekmece ilçesindeki ilkokul, ortaokul, imam hatip ortaokulu, anadolu-fen lisesi, imam hatip lisesi ve meslek lisesi okul türlerinde ve kademelerinde görev yapan 390 öğretmen gönüllui olarak katılmıştır. Veriler, "Kişisel Bilgi Formu” "Spirituiel İyi Oluş Ölçeği” ve "Oxford Mutluluk Ölçeği” kullanılarak toplanmıştır. Veriler, Pearson korelasyon analizi ve regresyon analizi ile çözümlenmiştir. Analiz sonucuna göre öğretmenlerin spiritüel iyi oluş aşkınlık ve doğayla uyum alt boyutları ile mutluluk arasında pozitif ve anlamlı ilişki bulunurken, spiritiiel iyi oluş anomi alt boyutu ile mutluluk arasında negatif ve anlamlı ilişki bulunmaktadır. Aşkınlık, öğretmenlerin mutluluğunu olumlu etkilerken, anomi olumsuz etkilemektedir. Bu etki büyüikliuğuinün orta düzeyde olduğu tespit edilmiştir. Araştırmada elde edilen bir diğer önemli bulguda spiritiiel iyi oluşun alt boyutlarından doğayla uyum öğretmenlerin mutluluklarını etkilememektedir.

Anahtar Kelimeler:

İyi oluş • Spirituiel iyi oluş • Mutluluk

Citation: Özgenel, M. \& Yılmaz, Ö. (2020). The relationship between spiritual well-being and happiness: An investigation on teachers. Spiritual Psychology and Counseling, 5, 287-300. https://dx.doi.org/10.37898/spc.2020.5.3.110 
Individuals may develop a sense of alienation and unhappiness in the face of constantly advancing technology, diverse means of communication, and everchanging living conditions. Since time immemorial, man has used both faith and religious techniques to overcome whatever problems that have constituted hurdles to their attainment of happiness. Being a multi-faceted living creature endowed with diverse physical, social, emotional, and mental capacities, man also has a spiritual element. Just as each of these aspects are interconnected, each one has its own needs. When one's spiritual needs, like finding meaning to one's life, feeling secure, expressing affection, and being loved are not satiated, that person finds him/herself in a spiritual abyss (Çınar \& Aslan, 2017).

Safeguarding one's spiritual framework is integral in securing that individual's happiness, as spiritual well-being (SWB) is just as important as physical health. Harmony between the body, brain, and soul is the criterion for judging a person to be completely healthy (Kavas \& Kavas, 2014). Individuals who accord spiritual values a central place in their lives are able to overcome different situations more easily (Kardaş, 2017). Several studies have from that spirituality reduces stress and has a positive impact on cardiac illnesses and high cholesterol (Daştan \& Buzlu, 2010). When individuals become distanced from spiritual values and lose their purpose in life, they experience various psychological problems, which in turn may cause to physical discomforts (Mutluer, 2006). When faced with events that cause sadness like illness and death, people begin to question their existences and, through spirituality, are able to give new meaning to their lives (Hiçdurmaz \& Öz, 2013). Those failing to discover or who are unable to live out their spirituality may feel loneliness and helpless while attempting to solve the problems they face. This feeling of helplessness pushes them to become distanced and alienated from society, which in turn causes divisions in the social fabric (Y1lmaz, 2019).

SWB is to search for the meaning and purpose of life and to recognize that there is a power greater than oneself. A person who has attained spiritual wellness is highly satisfied with life and is a self-actualized individual (Korkut Owen \& Owen, 2012). SWB is divided into two dimensions, the religious and the existential. A person's drawing closer to God or a higher power and the resulting spiritual fulfillment is religious wellness. A person's search for meaning and structuring his/her life accordingly is existential wellness. SWB shows that a person is fulfilled with the relationship s/he has with God, a higher power, him/herself, and his/her environment (Scott \& Agretsti, 1998). In defining spirituality, one group of researchers used submission to God or a higher power whereas other researchers restricted it to the person's own inner world.

Holding that spirituality is a way of life that transcends all religions, Murray and Zentner (1989) assert that spirituality seeks to investigate the very meaning and 
purpose of life itself while in a state of submission to God or a higher power (Cited in Baykal, 2018). As spirituality helps an individual attain meaning, knowledge, love, and hope, it interacts with the high level emotions causing happiness (Özen, 2010). Zinbauer et al. (1999) consider spirituality to be close to God and to build relationships with other living being. Chakraborty and Chakraborty (2004) define spirituality as orienting one's life toward a higher power as opposed to one's own ego (Cited in Örgev \& Gunalan, 2011). Schimdt-Wilk et al. (2000) describe spirituality as a person's internal awareness of him/herself (Cited in Örgev \& Gunalan, 2011). Spirituality is the state of submission to and trust in a higher power (e.g., God, an energy, nature...) than oneself in cases where s/he is powerless in the face of problems perceived to be otherwise insurmountable and by allowing the individual to find his/her purpose and path in life, enables him/her to recognize that $\mathrm{s} / \mathrm{he}$ is a part of the greater universe by bringing him/her closer to nature. Because spirituality incorporates hope, the drive to find meaning, and submission to a higher power when one is overwhelmed, it leads individuals toward developing positive feelings.

The dominance of positivist and materialist philosophy in Western thought has led to psychologists' neglect of man's spiritual dimension. With the increase of problems faced by humans and modern psychologies inability to deal effectively with these problems, researchers in the field of psychology have begun to investigate spirituality (Ekşi \& Kaya, 2016). Addressing all of man's diverse aspects, Maslow placed spiritual values on the highest rung of his hierarchy of needs. As material wealth has been found to be inadequate in solving the problems dominating modern life, in addition to the desire to live a peaceful and happy life, interest in spirituality has increased (Çınar \& Aslan, 2017). From the lowest to the highest rung on his hierarchy of needs, Maslow indicates physiological needs, the need for safety, the need for love and belonging, the need for respect, and the need for self-actualization. It is this final need that is related to the need for meaning in and to give meaning to life (Kizılırmak, 2015). Humans are the sole known living creature that seeks meaning and spirituality is the strongest point of reference in their efforts to give meaning to life. Those individuals unable to satisfy their need for meaning experience forlorn emotions like stress, anxiety, hopelessness (K1z1lırmak, 2015).

Happiness is defined as the feeling of pleasure, delight, contentment, prosperity, bliss, and good fortune experienced from the complete and continued fulfillment of one's ambitions (Turkish Language Institute [TDK], 2020). Happiness is related to individuals' contentment with life and those who consider themselves to have a high quality of live are defined as happy (Bülbül \& Giray, 2011). Happiness has both a physiological and psychological aspect to it. In order for a person to be happy, the brain must produce serotonin, and in order for the psychological effects of serotonin to occur, one must feel safe and have satisfied all of the prerequisite conditions of happiness (Baysal \& Aka, 2013). 
Happiness emerges as a result of the interaction between positive emotions, negative emotions, and life satisfaction. Positive emotions include joy, trust, and excitement whereas negative emotions refer to sadness, hate, and anger, among others. Life satisfaction pertains to fulfillment in a variety of human spheres. The prevalence of positive emotions over negative ones in an individual's life and high level of contentment indicates happiness (Ery1lmaz, 2011). According to Lyubomirski (2008), $50 \%$ of happiness depends on our genetic makeup, $40 \%$ on our behaviors, and $10 \%$ on our living conditions. Individuals may increase their level of happiness by having a positive attitude, learning how to deal with stress, prioritizing social relationships, practicing empathy, establishing a specific goal in life and striving to attain it, living out spirituality, and taking care of their physical health.

The concept of happiness entered into the field of psychology with the emergence of positive psychology and the subsequent studies conducted on it in this specific branch. The fact that positive psychology has shown psychology's focus on dealing with individuals' negative experiences to be inadequate and that it is necessary to examine, reveal, and strengthen individuals' positive and strong qualities has caused researchers to take an interest in and conduct research in this field. People's search for meaning in life following the destruction caused by the Second World War and Seligman's efforts to eliminate the shortcomings brought about by people's neglecting to realize their innate abilities influenced other specialists to begin working in this field, which would then give birth to positive psychology (Akçay, 2011). The concept of happiness in psychology is discussed following either a hedonic or eudaimonic approach (Koydemir \& Misir, 2015). Whereas the hedonic approach regards happiness as subjective well-being and is characterized by the prevalence of positive emotions over negative ones, the eudaimonic approach considers happiness to be psychological well-being and seeks to help individuals utilize their human potentials in the most effective way possible to attain self-actualization and meaning in life (Koydemir \& Misir, 2015).

Several studies on SWB and happiness appear in the Turkish literature. For example, there are studies examining the correlation between social gender perception and SWB (Keçeci, 2018); virtual identity and SWB, on the one hand, and narcissistic tendencies, on the other (Kardaş, 2017); alienation and death perception, on the one hand, and spiritual wellness, on the other (Erdoğan Kavalal1, 2019); spirituality and spiritual care perception, on the one hand, and professional satisfaction, on the other (Uygur, 2016); spiritual leadership and performance (Narc1kara, 2017); spiritual leadership and school culture (Özgenel \& Ankaralığlu, 2020); and test anxiety and spirituality (Şeftalici, 2017). Likewise, there are studies examining the correlation between happiness, on the one hand, and types of attachment, life satisfaction, and depression, on the other (Demirel, 2018); happiness and willingness to seek 
psychological help (Çolak, 2018); happiness and classroom management (Düzgün, 2016); happiness, on the one hand, and individuality and self-compassion, on the other (Duman, 2014); death anxiety, on the one hand, and social life and happiness, on the other (Akın, 2018); happiness and school climate (Özgenel \& Çetiner, 2019); and religious orientation and happiness (Kurnaz, 2015). Although it is assumed that school administrators' leadership styles indirectly influence teachers' happiness levels (Iş1k, 2009), a review of the literature reveals that the number of studies examining teachers' SWB and happiness levels is certainly limited. Teachers have the most important role in shaping the future of the culture and whether they are happy or not impacts their ability to fulfill their teaching duties. Since ascertaining teachers' SWB and happiness levels is of vital importance by dint of their being an undeniable human need, answers to the following questions were sought:

(i) Is there a meaningful correlation between teachers' SWB and happiness levels?

(ii) Do teachers' SWB levels predict their happiness levels?

\section{Method}

\section{Research Model}

This study has employed a relational survey model in its aim to determine the relationship between teachers' SWB and happiness levels, as it allows researchers to examine the relationship between two or more variables (Büyüköztürk, Çakmak, Akgün, Karadeniz, \& Demirel, 2017).

\section{Population and Sample}

The research universe consisted of 390 teachers employed in different types of schools throughout Istanbul's Küçükçekmece district. Participants were selected through stratified sampling, which is a sampling method that identifies subpopulations within the universe and represents them in the resulting sample in a proportionate manner (Özen \& Gül, 2007). School strata were divided into primary schools, middle schools, Imam-Khatib middle schools, Anatolian-science high schools, Imam-Khatib high schools, and vocational high schools. Using random sampling, three schools from each stratum were selected for inclusion and a total of 390 teachers employed in these schools volunteered to participate in the study. Of these 390 teachers, 279 (71.53\%) were females and $111(28.46 \%)$ were males, $109(27.94 \%)$ were thirty and younger, 185 (47.53\%) were between thirty-one and forty, 74 (18.97\%) were between forty-one and fifty, and $22(5.64 \%)$ were fifty or older. Whereas 318 $(81.53 \%)$ of the teachers had earned a bachelor's degree, $72(18.46 \%)$ had earned some sort of graduate degree. With regard to seniority, $11(29.74 \%)$ were first to 
fifth-year teachers, 96 (24.61\%) were sixth to tenth-year teachers, 55 (14.10\%) were eleventh to fifteenth-year teachers, $61(15.64 \%)$ were sixteenth to twentieth-year teachers, and $62(15.89 \%)$ were in their twenty-first year of teaching or higher. By school, 131 (35.58\%) were primary school teachers, 64 (16.41\%) were middle school teachers, 14 (3.58\%) were Imam-Khatib middle school teachers, 72 (18.46\%) were Anatolian-science high school teachers, 66 (16.92\%) were vocational high schools, and $43(11.02 \%)$ were Imam-Khatib high school teachers.

\section{Data Collection Tools and Data Collection}

We employed the Personal Information Form, the Spiritual Well-Being Scale and the Oxford Happiness Questionnaire to collect data for his study.

The Oxford Happiness Questionnaire (Short Form) [Turkish Version]. Developed by Hills and Argyle (2002), this questionnaire was adapted to Turkish by Doğan and Çötok (2011) with a study sample composed of 532 Turkish university students. The Turkish version of the questionnaire had a reliability coefficient (Cronbach's $\alpha$ ) of 0.74 and a test-retest reliability coefficient of 0.85 . Both an exploratory factor analysis (EFA) and confirmatory factor analysis (CFA) were conducted to determine the questionnaire's validity. The EFA revealed that, like the original version, the Turkish version was composed of a single factor, a fact which was then confirmed through a CFA conducted with Turkish university students. Accordingly, the Turkish version of the questionnaire was found to be valid and reliable. The items in the questionnaire are rated on a 5-point Likert-type scale (i.e., 1 = I completely disagree, 2 = I disagree, $3=\mathrm{I}$ partially agree, $4=\mathrm{I}$ agree, $4=\mathrm{I}$ completely agree), with a high score indicating that the individual had high levels of happiness (Doğan \& Çötok, 2011).

Spiritual Well-Being Scale. Developed by Ekşi and Kardaş (2017), this scale was developed after surveying the items of similar scales in the literature, compositions written to university students were read, and obtaining feedback from 17 field specialists. The scale's reliability and validity were verified with 865 adult individuals. Whereas the provisional scale contained 49 separate items, following an EFA and CFA, the final version of the scale was found to be composed of 29 items and three factors, namely, Transcendence, Harmony with Nature, and Anomie. Cronbach's $\alpha$ was .953 for Transcendence, .864 for Harmony with Nature, .853 for Anomie, and .886 for the entire scale. The items are rated on a 5-point Likert-type scale (i.e., $1=$ This does not apply to me at all, $2=$ This does not apply to me, $3=$ This applies to me a bit, $4=$ This applies to me very much, $5=$ This applies to me completely) and gauge adults' SWB. Items from the anomie subscale are reverse scored prior to calculating total scores (Ekşi \& Kardaş, 2017). 
Acknowledgment: In the study, permission was obtained from the researchers who developed data collection tools and adapted them to Turkish. In addition, necessary legal permissions were obtained from Istanbul National Education Directorate and Istanbul Governorship (Data: 19.04.2019, Number: 59090411-20-E.7973003).

\section{Data Analysis}

We obtained the necessary permissions from the researchers who had developed the scales used, the Istanbul Directory of National Education, and Istanbul Governorate to collect data for this study. We collected data on-site and in accordance with research training standards after going to the schools and informing the teachers about the research we were to conduct. The data obtained were analyzed using SPSS; however, prior to performing any such analysis, their kurtosis, skewness, and reliability coefficients were calculated to ascertain whether they showed normal distribution. Table 1 depicts the values calculated for these coefficients.

Table 1

Descriptive Values for Spiritual Well-Being and Oxford Happiness Questionnaire

\begin{tabular}{lcccccc}
\hline & $\mathrm{n}$ & Mean & $\mathrm{Sd}$ & Kurtosis & Skewness & Cronbach Alpha $a$ \\
\hline Spiritual Well-Being & 390 & 4.195 & .556 & -.605 & 1.414 & .812 \\
Happiness & 390 & 3.587 & .708 & -.416 & .027 & .763 \\
\hline
\end{tabular}

Table 1 reveals that the kurtosis and skewness values are between \pm 1.5 and show normal distribution. We used Pearson's correlation coefficient to ascertain as to whether there was any correlation between the independent (i.e., SWB) and the dependent (i.e., happiness) variables. We conducted a regression analysis and calculated the effect size to determine the predictive power of SWB. Whereas we conducted a correlation analysis to identify the relation between the variables, we performed a regression analysis to ascertain how much of a change occurred in the dependent variable (i.e., happiness) when the independent variable (i.e., SWB) experienced a single unit of change. The regression analysis found that both SWB and happiness were found to be continuous variables, that there was a linear correlation between them, that three values were not contained in the data set, that data showed normal distribution, that errors were random, and that there was a strong correlation between the independent variables.

\section{Findings}

This section describes the analyses conducted during our research. Table 2 presents the results of the analysis conducted to determine the relationship between teachers' spiritual well-being and happiness levels. 
Table 2

Relationship between Teachers'Spiritual Well-Being and Happiness Levels

\begin{tabular}{|c|c|c|c|c|c|c|c|c|}
\hline & Mean & $\mathrm{Sd}$ & & 1 & 2 & 3 & 4 & 5 \\
\hline \multirow{3}{*}{ 1-Transcendence } & \multirow{3}{*}{4.20} & \multirow{3}{*}{.874} & $\mathrm{r}$ & 1 & & & & \\
\hline & & & $\mathrm{p}$ & & & & & \\
\hline & & & $\mathrm{n}$ & 390 & & & & \\
\hline \multirow{3}{*}{ 2-Harmony with Nature } & \multirow{3}{*}{4.53} & \multirow{3}{*}{.657} & $\mathrm{r}$ & $.154 * *$ & 1 & & & \\
\hline & & & $\mathrm{p}$ & .002 & & & & \\
\hline & & & $\mathrm{n}$ & 390 & 390 & & & \\
\hline \multirow{3}{*}{ 3-Anomie } & \multirow{3}{*}{2.21} & \multirow{3}{*}{.757} & $\mathrm{r}$ & -.099 & $.211 * *$ & 1 & & \\
\hline & & & $\mathrm{p}$ & .051 & .000 & & & \\
\hline & & & $\mathrm{n}$ & 390 & 390 & 390 & & \\
\hline \multirow{3}{*}{ 4-Spiritual Well-Being (Total) } & \multirow{3}{*}{4.19} & \multirow{3}{*}{.556} & $\mathrm{r}$ & $894 * *$ & $.473 * *$ & -.436 & 1 & \\
\hline & & & $\mathrm{p}$ & .000 & .000 & .000 & & \\
\hline & & & $\mathrm{n}$ & 390 & 390390 & & 390 & \\
\hline \multirow{3}{*}{ 5-Happiness } & \multirow{3}{*}{3.58} & \multirow{3}{*}{.708} & $\mathrm{r}$ & $.349 * *$ & $.161 * *$ & $-.462 * *$ & $.475 * *$ & 1 \\
\hline & & & $\mathrm{p}$ & .014 & .001 & .000 & .000 & \\
\hline & & & $\mathrm{n}$ & 390 & 390 & 390 & 390 & 390 \\
\hline
\end{tabular}

$* * \mathrm{p}<.01$

Table 2 indicates that teachers' happiness levels have a positive and moderate correlation with transcendence $(\mathrm{r}=.349 ; \mathrm{p}<.05)$, a positive and low correlation with harmony with nature $(\mathrm{r}=.161 ; \mathrm{p}<.05)$, a negative and moderate correlation with anomie $(\mathrm{r}=-.462 ; \mathrm{p}<.05)$, and a positive and moderate correlation with general SWB $(\mathrm{r}=.475 ; \mathrm{p}<.05)$, all of which were statistically significant.

Table 3 presents that results of the multiple regression analysis conducted to determine the predictive power of teachers' SWB levels on their happiness levels.

Table 3

Results of the Regression Analysis Conducted to Determine How Well Spiritual Well-Being Predicts Teachers' Happiness Levels

\begin{tabular}{llccccc}
\hline & Variable & B & Standard Error & B & $\mathrm{t}$ & $\mathrm{p}$ \\
\hline \multirow{4}{*}{ Model I } & 3.322 & .278 & & 11.963 & .000 \\
& Constant & .245 & .035 & .303 & 7.041 & .000 \\
& Transcendence & .026 & .047 & .024 & .559 &. $\mathbf{5 7 7}$ \\
& Harmony with Nature & -.400 & .041 & -.427 & -9.830 & .000 \\
\hline
\end{tabular}

$R=.554 ; R^{2}=.307 ; F=56.974 ; p=.000$

Table 3 reveals that whereas transcendence and anomie are significant predictors happiness levels $(\mathrm{p}<.05)$, harmony with nature is not $(\mathrm{p}>.05)$. Both transcendence and anomie were found to explain $30 \%$ of the total variance in happiness levels $(\mathrm{R}=.553$; $\left.\mathrm{R}^{2}=.30 ; \mathrm{F}=85.456 ; \mathrm{p}=.05\right)$. The $\beta$ coefficient reveals that while anomie adversely affected teachers' happiness levels, transcendence had a positive effect on them.

We used Cohen's (1988) $f^{2}$ as the criterion to calculate the effect size of the results of the multiple regression analysis. We used the formula $f^{2}=\mathrm{R}^{2} /\left(1-\mathrm{R}^{2}\right)$ to calculate $f^{2}$ values and considered $.02 \leq f^{2}<.15$ to constitute a small effect, $.15 \leq f^{2}<.35$ a 
medium effect, and $.35 \leq f^{2}$ a large effect for the purposes of our study (Cohen, 1988). Consequently, we calculated the $f^{2}$ value to determine the effect size that SWB has on teachers' happiness levels. This study found that the effect size of teachers' SWB had a medium effect size of $f^{2}=.30 /(1-.30)=.21$ on their happiness levels.

\section{Conclusion and Discussion}

This study sought to analyze the relationship between teachers' spiritual wellbeing and happiness levels and has concluded that happiness is positively and significantly correlated with both transcendence and harmony with nature and negatively and significantly correlated with anomie. Both anomie and transcendence were both found to have a moderate impact on teachers' happiness, with anomie having a relatively greater effect. As teachers' transcendence levels increased, so did their happiness levels experience an increase whereas anomie had a detrimental effect on teachers' happiness levels.

In the literature, anomie is described as a societal erosion of cultural values, purpose, and desire to abide by society's rules that then leads to alienation, anarchy, and hopelessness (Bayhan, 1995). In other words, anomie means the weakening of the bond between an individual and society's rules or the lack of desire to follow these rules. Since anomie is detrimental to SWB (Şirin, 2019), we expected to identify a negative correlation between it and happiness. Transcendence is defined as an individual's submission to an entity more powerful than him/herself (Acar, 2016). Consequently, although anomie had a negative impact on teachers' happiness, it had a positive impact on transcendence. Though anomie did not have a significant effect on harmony with nature, this specific sub-dimension of well-being may be helpful in giving meaning to one's life. SWB generally depends on what one understands the meaning and purpose of life to be and on realizing that there is a greater power than oneself. An individual who has attained spiritual wellness is a person who is highly satisfied with life and who feels a sense of wholeness (Korkut-Owen \& Owen, 2012). In the literature, Gardaş (2017) found there to be a negative correlation between narcissism and SWB whereas Holder, Coleman, and Wallace (2010) found a significant, positive correlation between spirituality and happiness. Brome, Owens, Allen, and Vevaina (2000) reported that individuals with high levels of spirituality are also highly satisfied with life. Fehring, Miller, and Shaw (1997), however, found spiritual wellness to have a positive and meaningful correlation with hope and positive emotions. Ivtzan, Chan, Gardner, and Prashar (2013), Jahan and Khan (2014), Yoon et al. (2015), and Saleem (2017) all found a positive and meaningful correlation between spirituality and psychological well-being. Cotton, Levine, Fitzpatrick, Dold, and Targ (1999) found that patients with high levels of SWB were more hopeful and were less likely to suffer from depression compared to those with relatively weaker SWB. In his study with oncology patients, Erdoğan (2019) concluded that as patients' spiritual wellness levels increased, they were 
able to find greater meaning in life and suffered less from loneliness. Other studies have reported that having a relationship with nature had a favorable impact on individuals' happiness (Nisbet, Zelenski, \& Murphy, 2011) and led to lower levels of depression (Zelenski \& Nisbet, 2014). These findings support the notion that individuals' SWB levels impact happiness. In other words, SWB boosts positive emotions like happiness and may even mitigate negative emotions.

As this study was realized solely with teachers employed in Küçükçekmece, Istanbul, repeating this study with different sample groups in different regions and provinces while incorporating a greater number of variables and different descriptive techniques will aid in further expounding on our findings.

\section{References}

Akbulut, E. (2013). Eğitim fakültesi okulöncesi anabilim dalı programında yer alan müzik eğitimi dersi hedeflerinin gerçekleşme düzeylerine ilişkin ölçek geliştirme çalışması. Pamukkale Üniversitesi Eğitim Fakültesi Dergisi, 33(1), 1-10.

Akçay, V. H. (2011). Pozitif psikolojik sermayenin kişisel değerler bakımından iş tatminine etkisi ve bir araştırma (Doktora tezi, İstanbul Üniversitesi, Sosyal Bilimler Enstitüsü, İstanbul). https:// tez.yok.gov.tr/UlusalTezMerkezi/ adresinden edinilmiştir.

Akın, E. (2018). Yaşlılarda ölüm kaygısının sosyal yaşamla ve mutlulukla ilişkisi (Tıpta uzmanlık tezi, Dokuz Eylül Üniversitesi, Tıp Fakültesi, İzmir). https://tez.yok.gov.tr/UlusalTezMerkezi/ adresinden edinilmiştir.

Akın, H., B., \& Şentürk, E. (2012). Bireylerin mutluluk düzeylerinin ordinal lojistik regresyon analizi ile incelenmesi. Öneri, 10(37), 183-193.

Arslan, Y. (2018). Öğretmenlerin farklılıkların yönetimi yaklaşımlarına ilişkin algıları ile örgütsel mutluluk algıları arasındaki ilişki (Doktora tezi, Kocaeli Üniversitesi, Sosyal Bilimler Enstitüsü, Kocaeli). https://tez.yok.gov.tr/UlusalTezMerkezi/ adresinden edinilmiştir.

Ay, Y. \& Gürsu, O. (2018). Din, manevi iyi oluş ve yaşlılık. Uluslararası Sosyal Araşstırmalar Dergisi, 11(61), 1176-1190.

Bayhan, V. (1995). Üniversite gençliğinde anomi ve yabancılaşma (İnönü üniversitesi uygulaması) (Doktora tezi, İnönü Üniversitesi, Sosyal Bilimler Enstitüsü, Malatya). https://tez.yok.gov.tr/ UlusalTezMerkezi/ adresinden edinilmiştir.

Baykal, E. (2018). Spiritüelite (ruhsallık) ve iş ortamında anlam arayışı. Alanya Akademik Bakış Dergisi, 2(1), 11-25.

Baysal, S. \& Aka, Ç. İ. (2013). Bir pazarlama stratejisi olarak mutluluk temasının markalar tarafından kullanılması: mutluluk temelli pazarlama üzerine bir araştırma. Sosyal ve Beşerî Bilimler Dergisi, 5(1), 84-93.

Brome, D. R., Owens, M. D., Allen, K., \& Vevaina, T. (2000). An examination of spirituality among African American women in recovery from substance abuse. Journal of Black Psychology, 26(4), 470-486.

Brown, I. T., Chen, T., Gehlert, N.C., \& Piedmont, R. L. (2013). Age and gender effects on the assessment of spirituality and religious sentiments (ASPIRES) scale: A cross-sectional analysis. Psychology of Religion and Spirituality, 5(2), 90-98. 
Bulut, A. (2015). Ortaöğretim öğretmenlerinin örgütsel mutluluk algllarının incelenmesi (Doktora tezi, Gaziantep Üniversitesi, Eğitim Bilimleri Enstitüsü, Gaziantep). https://tez.yok.gov.tr/ UlusalTezMerkezi/ adresinden edinilmiştir.

Bülbül, Ş. \& Giray, S. (2011). Sosyodemografik özellikler ile mutluluk algııı arasındaki ilişki yapısının analizi. Ege Akademik Baklş Dergisi, 11(5), 113-123.

Büyüköztürk, Ş., Çakmak, E. K., Akgün, Ö. E., Karadeniz, Ş., \& Demirel, F. (2017). Bilimsel araştırma yöntemleri. Pegem.

Cohen, J. (1988). Statistical Power analysis for the behavioral sciences (2nd Ed.). Lawrence Earlbaum Associates.

Cotton, S. P., Levine, E., Fitzpatrick, C., Dold, K., \& Targ, E. (1999). Exploring the relationships among spiritual well-being, quality of life, and psychological adjustment in women with breast cancer. Psycho Oncology, 8(5), 429-438.

Çelik, A., Özdemir, F. Durmaz, H. \& Pasinlioğlu, T. (2014). Hemşirelerin maneviyat ve manevi bakımı algılama düzeyleri ve etkileyen bazı faktörlerin belirlenmesi. Hacettepe Üniversitesi Hemşirelik Fakültesi Dergisi, 3(1), 1-12.

Çınar, F. \& Aslan, F. E. (2017). Spiritüalizm ve hemşirelik: Yoğun bakım hastalarında spiritüel bakımın önemi. GOP Taksim EAH, Jaren, 3(1), 37-39.

Çolak, E. (2018). Sosyal fayda projelerinde gönüllü çalışan üniversite ögrrencilerinde mutluluk ve psikolojik yardım aramaya gönüllülük düzeylerinin değerlendirilmesi (Yüksek lisans tezi, Beykent Üniversitesi, Sosyal Bilimler Enstitüsü, İstanbul). https://tez.yok.gov.tr/ UlusalTezMerkezi/ adresinden edinilmiştir.

Daştan, N. B. \& Buzlu, S. (2010). Meme kanseri hastalarında maneviyatın etkileri ve manevi bakım. Maltepe Üniversitesi Hemşirelik Bilim ve Sanatı Dergisi, 3(1), 75.

Demirel, C. (2018). Yetişkinlerde bağlanma stillerinin mutluluk yaşam doyumu ve depresyon ile ilişkisinin incelenmesi (Yüksek lisans tezi, Işık Üniversitesi, Sosyal Bilimler Enstitüsü, İstanbul). https://tez.yok.gov.tr/UlusalTezMerkezi/ adresinden edinilmiştir.

Doğan, T. \& Çötok, N. (2011). Oxford mutluluk ölçeği kısa formunun türkçe uyarlaması: Geçerlik ve güvenirlik çalışması. Türk Psikolojik Danışma ve Rehberlik Dergisi, 4(36), 161-172.

Duman, S. (2014). Öğretmen adaylarında özgünlük ve öz duyarlığın mutluluk ile ilişkisinin incelenmesi (Yüksek lisans tezi, Karadeniz Teknik Üniversitesi, Eğitim Bilimleri Enstitüsü, Trabzon). https://tez.yok.gov.tr/UlusalTezMerkezi/ adresinden edinilmiştir.

Duran, A. (2016). Okul yöneticilerinin mutluluk düzeylerinin öz yeterlilikleriyle ilişsisi (Yüksek lisans tezi, Gaziosmanpaşa Üniversitesi, Eğitim Bilimleri Enstitüsü, Tokat). https://tez.yok.gov. tr/UlusalTezMerkezi/ adresinden edinilmiştir.

Düzgün, O. (2016). Ortaokulda görev yapmakta olan ögretmenlerin mutluluk düzeyleri ile sinıf yönetimi becerileri arasındaki ilişsi (Yüksek lisans tezi, Gaziosmanpaşa Üniversitesi, Eğitim Bilimleri Enstitüsü, Tokat). https://tez.yok.gov.tr/UlusalTezMerkezi/ adresinden edinilmiştir.

Eğlence, R., \& Şimşek, N. (2014). Hemşirelerin Maneviyat ve manevi bakım hakkındaki bilgilerinin değerlendirilmesi. Acıbadem Üniversitesi Să̆lık Bilimleri Dergisi, 5(1), 48-53.

Ekşi, H. \& Kaya, Ç. (2016). Manevi yönelimli psikoterapi ve psikolojik danışma. Kaknüs Yayınları.

Emirza, E. G. (2018). Kadın konukevlerinde kalan şiddet mağduru kadınların çocukluk çağ travmaları, spiritüellik ve çatışma yöntemleri açısından psikolojik belirtilerin değerlendirilmesi (Yüksek lisans tezi, Gazi Üniversitesi, Sağlık Bilimleri Enstitüsü, Ankara). https://tez.yok.gov. tr/UlusalTezMerkezi/ adresinden edinilmişstir. 
Erdoğan K. T. (2019). Onkoloji hastalarında yalnızlık ve ölüm algısı ile spiritüel iyilik hali arasındaki ilişki (Yüksek lisans tezi, Ondokuz Mayıs Üniversitesi, Sağlık Bilimleri Enstitüsü, Samsun). https://tez.yok.gov.tr/UlusalTezMerkezi/ adresinden edinilmiştir.

Eryılmaz, A. (2011). Ergen öznel iyi oluşunun, öznel iyi oluşu arttırma stratejilerini kullanma ile yaşam amaçlarını belirleme açısından incelenmesi. Düşünen Adam Psikiyatri ve Nörolojik Bilimler Dergisi, 24(1), 44-51.

Fehring, R. J., Miller, J. F., \& Shaw, C. (1997). Spiritual well-being, religiosity, hope, depression, and other mood states in elderly people coping with cancer. In Oncology Nursing Forum, 24(4), 663-671.

Gomez, R. \& Fisher, J.W. (2005). The spiritual well-being questionnaire: Testing for model applicability, measurement and structural equivalencies, and latent mean differences across gender. Personality and Individual Differences, 39(8), 1383- 1393.

Gönenç, İ. M., Akkuzu, G., Durdun Altın, R. \& Möroy, P. (2016). Hemşirelerin ve ebelerin manevi bakıma ilişkin görüşleri. Gümüşhane Üniversitesi Sağllk Bilimleri Dergisi, 5(3), 34-38.

Göral, Ş. (2013). İnternet ortamında geçirilen boş zamanın üniversite öğrencilerinin mutluluk ve yaşam doyum değerlerine etkisi (Yüksek lisans tezi, Gazi Üniversitesi, Sosyal Bilimler Enstitüsü, Ankara). https://tez.yok.gov.tr/UlusalTezMerkezi/ adresinden edinilmiştir.

Hiçdurmaz, D. \& Öz, F. (2013). Stresle baş etmenin bir boyutu olarak spiritüelite. Anadolu Hemşirelik ve Sağllk Bilimleri Dergisi, 16(1), 50-56.

Holder, M. D., Coleman, B. \& Wallace, J. M. (2010). Spirituality, religiousness, and happiness in children aged 8-12 years. Journal of Happiness Studies, 11(2), 131-150.

Işı, M. (2009). Okul yöneticilerinin etik liderlik özellikleri ile örgütsel bağlılık arasındaki ilişki (Yüksek lisans tezi, Beykent Üniversitesi, Sosyal Bilimler Enstitüsü, İstanbul). https://tez.yok. gov.tr/UlusalTezMerkezi/ adresinden edinilmiştir.

Ivtzan, I., Chan, C. P., Gardner, H. E. \& Prashar, K. (2013). Linking religion and spirituality with psychological well-being: Examining self-actualisation, meaning in life, and personal growth initiative. Journal of Religion and Health, 52(3), 915-929.

Jahan, M. \& Khan, S. (2014). Psychological well-being: Spirituality and successful aging. Indian Journal of Health and Wellbeing, 5(7), 68.

Kardaş, S. (2017). Sanal kimlik ve spiritüel iyi oluşun üniversite öğrencilerinin narsistlik eğilimlerini yordayıcılığ (Doktora tezi, Marmara Üniversitesi, Sosyal Bilimler Enstitüsü, İstanbul). https:// tez.yok.gov.tr/UlusalTezMerkezi/ adresinden edinilmiştir.

Kavas, E. \& Kavas, N. (2014). Manevi destek algısı (MDA) ölçeği: Geliştirilmesi, geçerliği ve güvenirliği. International Periodical for the Languages Literature and History of Turkish or Turkic, 9(2), 905-907.

Keçeci, B. (2018). Evli kadınların psikolojik istismar profillerinin toplumsal cinsiyet algıları ve spiritüel iyi oluşları açısından incelenmesi (Yüksek lisans tezi, Marmara Üniversitesi, Eğitim Bilimleri Enstitüsü, İstanbul). https://tez.yok.gov.tr/UlusalTezMerkezi/ adresinden edinilmiştir.

Kızılırmak, Ö. (2015). Genç yetişsinlerde yaşamda anlamın maneviyat ve kişilik özellikleri açısından incelenmesi (Yüksek lisans tezi, Gazi Üniversitesi, Eğitim Fakültesi, Ankara). https:// tez.yok.gov.tr/UlusalTezMerkezi/ adresinden edinilmiştir.

Korkut-Owen, F. \& Owen, D. (2012). İyilik hali yıldızı modeli, uygulanması ve değerlendirilmesi. Uluslararası Avrasya Sosyal Bilimler Dergisi, 3(9), 24-33. 
Koruklu, N., Feyzioğlu, B., Özenoğlu Kiremit, H., \& Aladağ, E. (2013). Öğretmenlerin iş doyumu düzeylerinin bazı değişkenlere göre incelenmesi. Mehmet Akif Ersoy Üniversitesi Eğitim Fakültesi Dergisi, 13(25), 119-137.

Kostak, M.A., Çelikalp, Ü., \& Demir, M. (2010). Hemşire ve ebelerin maneviyat ve manevi bakıma ilişkin görüşleri. Maltepe Üniversitesi Hemşirelik Bilim ve Sanatı Dergisi, 25-218.

Koydemir, S. \& Mısır, S. (2015). Benlik kurguları ve mutluluk: Deneysel bir hazırlama çalışması. Türk Psikolojik Danışma ve Rehberlik Dergisi, 5(44), 49-60.

Köse, S. K. (2008). Korelasyon ve regresyon analizi. https://file.toraks.org.tr/ TORAKSFD23NJKL4NJ4H3BG3JH/mse-ppt-pdf/Kenan_KOSE3.pdf

Kurnaz, M. (2015). İlk yetişkinlerde dini yönelim-mutluluk ilişkisi (Yüksek lisans tezi, Süleyman Demirel Üniversitesi, Sosyal Bilimler Enstitüsü, Isparta). https://tez.yok.gov.tr/ UlusalTezMerkezi/ adresinden edinilmiştir.

Lyubomirski, S. (2008). The how of happiness: a scientific approach to getting the life you want. New York: Penguin Press.

Mutluer, S. (2006). Özgüven oluşmasında manevi değerlerin rolü (Yüksek lisans tezi, Ankara Üniversitesi, Sosyal Bilimler Enstitüsü, Ankara). https://tez.yok.gov.tr/UlusalTezMerkezi/ adresinden edinilmiştir.

Narcıkara, E. (2017). Spiritüel liderlik davranışının algılanan performans üzerine etkisi (Doktora tezi, Yıldız Teknik Üniversitesi, Sosyal Bilimler Enstitüsü, İstanbul). https://tez.yok.gov.tr/ UlusalTezMerkezi/ adresinden edinilmiştir.

Nisbet, E. K., Zelenski, J. M., \& Murphy, S. A. (2011). Happiness is in our nature: Exploring nature relatedness as a contributor to subjective well-being. Journal of Happiness Studies, 12(2), 303-322.

Örekli, M., (2018). Anadolu imam hatip liseleri meslek dersleri öğretmenlerinin öğrenciler tarafından epistemik otorite olarak görülmesi üzerine nitel bir araştırma (Yüksek lisans tezi, Necmettin Erbakan Üniversitesi, Sosyal Bilimler Enstitüsü, Konya). https://tez.yok.gov.tr/ UlusalTezMerkezi/ adresinden edinilmiştir.

Örgev,M.\&Günalan,M.(2011).İşyerimaneviyatıüzerineeleştirelbirdeğerlendirme.Kahramanmaraş Sütçü İmam Üniversitesi İktisadi ve İdari Bilimler Fakültesi Dergisi, 1(2), 51-64.

Özbaşaran, F., Ergül, Ş., Bayık Temel, A., Gürol Aslan, G., \& Çoban, A. (2011). Turkish nurses' perceptions of spirituality and spiritual care. Journal of Clinical Nursing, 20, 21-22.

Özen, Y. (2010). Tanrı- sen ve ben üçümüzün yolu- pastoral psikoloji ve danışmanlığın gerekliliği üzerine. Din Bilimleri Akademik Araştırma Dergisi, 10(2), 41-57.

Özen, Y. \& Gül, A. (2007). Sosyal ve Eğitim Bilimleri Araştırmalarında Evren-Örneklem Sorunu. Atatürk Üniversitesi Kazım Karabekir Eğitim Fakültesi Dergisi, 0(15), 394-472.

Özgenel, M., \& Ankaralığlu, S. (2020). The effect of school administrators' spiritual leadership style on school culture. Spiritual Psychology and Counseling, 5(2), 137-165.

Özgenel, M. ve Çetiner, R. (2019). Okul ikliminin öğrencilerin mutluluğuna etkisi. V. Uluslararası TURKCESS Eğitim ve Sosyal Bilimler Kongresi. 27-29 Haziran 2019/İstanbul.

Özkan, A. (2017). İlkokul ve ortaokul ögretmenlerinin iş doyumu düzeyi (Balıkesir ili merkez ilçeler örneği) (Yüksek lisans tezi, Balıkesir Üniversitesi, Sosyal Bilimler Enstitüsü, Balıkesir). https:// tez.yok.gov.tr/UlusalTezMerkezi/ adresinden edinilmiştir.

Öztürk, A. (2015). Öğretmenlerin sahip oldukları yaşam amaçları ve sosyal desteğin öznel iyi oluş üzerindeki yordayıcı rolü. Uluslararası Türk Eğitim Bilimleri Dergisi, 338-347. 
Saleem, R. (2017). Spirituality in relation to quality of life and psychological well-being among religious and non-religious persons. Indian Journal of Positive Psychology, 8(3), 420- 424.

Sancak, T. (2019). Öğretmenlerin okullardaki mekân düzenlemelerine ilişkin memnuniyetleri ile mutlulukları ve örgütsel bağlllıkları arasındaki ilişki (Yüksek lisans tezi, İstanbul Sabahattin Zaim Üniversitesi, Sosyal Bilimler Enstitüsü, İstanbul). https://tez.yok.gov.tr/UlusalTezMerkezi/ adresinden edinilmiştir.

Scott, E. L. \& Agretsti, A. A. (1998). Factor analysis of the spiritual well-being scale and ts clinical utility with psychiatric inpatients. Journal for The Scientific Study of Religion, 37(2), 314-322.

Şeftalici, B. (2017). Lise son sinıf öğrencilerinde sınav kaygısı ve maneviyat Şanlıurfa-Viranşehir örneği (Yüksek lisans tezi, Çukurova Üniversitesi, Sosyal Bilimler Enstitüsü, Adana). https:// tez.yok.gov.tr/UlusalTezMerkezi/ adresinden edinilmiştir.

Şirin, T. (2019). Evli çiftlerin spiritüel iyi oluşları ile evlilik doyumları arasındaki ilişki. Ekev Akademi Dergisi, 77, 389-410.

Türk Dil Kurumu (2020). Güncel Türkçe Sözlük. https://sozluk.gov.tr/

Uygur, D. (2016). Hemşirelerin spiritüalite ve spiritüel bakım algısının belirlenmesi ve iş doyumu ile arasındaki ilişskinin incelenmesi (Yüksek lisans tezi, Abant İzzet Baysal Üniversitesi, Sağlık Bilimleri Enstitüsü, Bolu). https://tez.yok.gov.tr/UlusalTezMerkezi/ adresinden edinilmiştir.

Wong K.F, Lee L.Y.K, \& Lee J.K.L. (2008). Hong Kong enrolled nurses' perceptions of spirituality and spiritual care. International Nursing Review, 55, 333-340.

Yılmaz, M. \& Okyay, N. (2009). Hemşirelerin maneviyat ve manevi bakıma ilişkin görüşleri. Hemşirelikte Araştırma Geliştirme Dergisi, 11(3), 41-52.

Yoon, E., Chang, C. C. T., Clawson, A., Knoll, M., Aydin, F., Barsigian, L., \& Hughes, K. (2015). Religiousness, spirituality, and eudaimonic and hedonic well-being. Counselling Psychology Quarterly, 28(2), 132-149.

Zelenski, J. M., \& Nisbet, E. K. (2014). Happiness and feeling connected: The distinct role of nature relatedness. Environment and Behavior, 46(1), 3- 23.

Zinnbauer, B. J., Pargament, K. I. ve Scott, A. B. (1999). The emerging meanings of religiousness and spirituality: Problems and prospects, Journal of Personality, 67(6), 889-916. 